\title{
Exploring Reflections of Lecturers on Ethics in the Accounting Curriculum: A Case Study of Ukzn and Unizulu, South Africa
}

\author{
Ankur Ratnam Tewari ${ }^{1} \&$ Lokesh Ramnath Maharajh ${ }^{1}$ \\ ${ }^{1}$ School of Education, University of KwaZulu-Natal, Durban, South Africa \\ Correspondence: Lokesh Ramnath Maharajh, Lecturer, School of Education, University of KwaZulu-Natal, Durban, \\ South Africa.
}

Received: September 25, 2020

Accepted: November 22, 2020

Online Published: March 18, 2021

doi:10.5430/ijfr.v12n4p65

URL: https://doi.org/10.5430/ijfr.v12n4p65

\begin{abstract}
The accounting profession has changed considerably over the past twenty years or so. This has led to the new accounting curriculum undergoing many changes such as increased financial fraud coverage, laws relating to financial crime and globalisation and financial security issues. However, there have been many financial scandals in the $21^{\text {st }}$ century in the African and American context. Several notable incidents of ethical misconduct such as Enron, Klynveld Peat Marwick Goerdeler (KPMG), and Satyam (which negatively impact the world economy) are examples of misuse of accounting to cover the truth. Lack of ethics is believed to be responsible for most of these scandals. This study, therefore, aims at understanding the reflections on the issue of ethics in teaching accounting. The study followed a case study approach and involved a small sample of accounting lecturers from UKZN and UNIZULU. The study's findings suggest that special topical issues on ethics should be taught in each accounting course. For example, in the auditing course, ethical procedures should be touched upon, and students should be sensitized about accountants' ethical behaviour.
\end{abstract}

Keywords: accounting, ethics, curriculum, profession, SAICA

\section{Introduction}

The accounting profession has changed considerably over the past twenty years or so. It is one of the oldest and most noble professions globally (South African Institute of Chartered Accountants, SAICA (n.d.) www.saica.co.za; Kelly, 2017). Students are attracted to this profession, for it leads to a highly financially rewarding career. The accounting profession has also undergone various ethical changes in the past two decades or so. The new accounting curriculum has undergone many changes, such as increased coverage of financial fraud, laws relating to financial crime and globalisation and financial security issues (SAICA, 2018). However, there have been many financial scandals in the $21^{\text {st }}$ century in the African and American context. Several notable incidents of ethical misconduct such as Enron, Klynveld Peat Marwick Goerdeler (KPMG), and Satyam (which negatively impact the world economy) are examples of misuse of accounting to cover the truth. Accounting ethics refers to the standards of right and wrong conduct that apply to the accounting profession (McPhail, 2001; Chen, Gotti, Kang, \& Wolfe, 2018). This concept has gained significant attention in the global world, and the accounting profession has to ensure that ethical accounting procedures in the practical world are followed.

The accounting scandals in the early 2000s have had a devastating effect on the accounting profession's reputation (Williams \& Elson, 2010). The public perceives the scandals as a lack of ethics in the profession. Russell and Smith (2003) accused academia of fault. They noted:

"if we are looking for a primary contributing cause of corporate malfeasance at firms, we need to look no further than the classrooms of schools and university accounting programmes that have not significantly adapted their methods of instruction or approach to management education over the last fifty to sixty years" (Russell and Smith, 2003, p.1).

Academicians have hence thought of how it should be taught in the accounting curriculum. Ethics needs to be incorporated by educators to bring forth ethical considerations with good quality and integrity (Wyatt \& Gaa, 2004). However, accounting educators are still seen to be focusing on the teaching and learning activities to finish the 
accounting syllabus towards the needs of the examinations rather than inculcating the right accounting ethics and maintaining integrity in the workplace (Ahmad, 2007).

Chawla and Nanhas (2015) stated that university accounting students need a single course in ethics to deal with various situations and improve their ethical reasoning skills. Accounting educators viewed the incidents of corporate scandal in the accounting world as a wake-up call to realize the need to incorporate good values to the students and the importance of accounting to society and the economy (Titard et al., 2004; Chawla et al., 2015). Therefore, educators should adopt the attitudes, values, and philosophy of progressive education, be responsible and honourable to develop the younger generation with moral qualities and character, high integrity (Waddock, 2005). The values and ethics should be incorporated in school and university to generate ethical and good quality students who would be responsible for the work entrusted to them (Smith, 2003; Bayou et al., 2011).

Improving the understanding and absorption of ethics' principles requires teaching ethics from early days in schools and universities. Ethics has been an essential part of Chartered Accountant (CA) (SA) training in South Africa. The profession mandates its members to follow the routes of accountability, honesty, integrity, and professional competence (SAICA, 2018). The problem with the teaching of ethics is that CAs cannot apply the theories efficiently in the workplace. The university level problem is that students understand lecture content well enough but lack skills of ethics application (Candy, 1995). There are two basic approaches towards teaching ethics to students: 1) Integrated approach, 2) Isolated approach. The proponents of an integrated approach of teaching ethics recommend that ethics be made part of each course and be taught along with the technical content (Loeb, 1988; Cheng, 2007). The isolated teaching approach requires that ethics be taught as a separate subject in the curriculum (Wright \& Bline, 1998). However, knowledge of ethics alone is no guarantee of moral character (Prozesky, 2001; Cowton \& Cummins, 2003; Chan \& Leung, 2006).

Cavanaugh (1993, p. 114) noted that in practice, "professionals acquire much more learning from readings, discussions, with colleagues and experience than through formal classroom training". According to Mujtaba (2005) and Riley (2012), ethics is the branch of philosophy that theoretically, rationally, and reasonably determines right from wrong and moral from immoral. It is recommended that educators help students develop an effective system for learning right and wrong to translate these learned skills into practice. Ethics should be taught continuously in schools and universities (Massey \& Van Hise, 2009). It should reflect the socio-economic conditions of the students and cause effective social change. Given the above discussion, it will be useful to understand accounting lecturers' reflections towards ethics learning and what they feel about ethics. This will strengthen the understanding and application potential of ethics teaching in the classroom.

The lack of ethics has played an important role in the downfall of many companies such as Enron, Satayam, and others. Ethics hence plays a decisive role in determining the operational future of businesses. This has brought a curriculum consciousness in the accounting discipline. Many experts now insist that ethics be taught in schools and universities, and not just to be assumed that everyone understands the science of ethics well. Professional accounting bodies now insist on including ethics in the accounting curriculum around the world. In the South African context, SAICA has introduced the ethics module in the curriculum; this makes both students and teachers/lecturers reflect on ethics. This study aims at understanding the reflections on the issue of ethics in teaching accounting. No such research has been done in the country so far.

Some experts claim that new laws may not restore credibility; instead, confidence in the profession would only be restored by ethical leadership (Dellaportas et al., 2005). Hence enriching ethics in accounting education and improving its members' moral behavior is viewed as one of the ways to restore the credibility of the profession (McPhail 2001). Understanding the role of ethics in teaching and how lecturers reflect upon it will strengthen the classroom's ethical teaching issues. Understanding the accounting curriculum concerning local ethics issues will pave the way for further curriculum development in making it holistic and ethically sound. The study elicits the lecturers' reflection on teaching ethics and in inculcating ethical thinking among accounting students. There are two main objectives of the study:

1) To study the status of ethics in the accounting curriculum at selected universities of UKZN and UNIZULU.

2) To study the reflections of lecturers' towards ethics in the accounting curriculum at the above universities

\section{Methodology and Data}

The current study is done using the interpretive paradigm in a qualitative framework. As per the Oxford English dictionary, a paradigm is "a pattern or model, an exemplar; a typical instance of something, an exemplifier (Oxford English Dictionary, $3^{\text {rd }}$ Edition, 2000). In social sciences, the word paradigm generally refers to a world view, a 
perspective, a way of exemplifying the real-world complexity to understand the phenomenon well (Patton, 1990). A paradigm is an interpretive framework guided by beliefs, feelings, and impressions. According to Johnson and Christensen (2014, chapter 2), a paradigm is a perspective "based on a set of assumptions, concepts, values, and practices". In the study context, the interpretive paradigm was used to understand the status of ethics in the accounting curriculum. The interpretive paradigm aims to understand the participant's views on a particular subject (phenomena) through a subjective understanding. This paradigm is useful for the study for two reasons: 1) the researcher aimed to study and explore the reflections of lecturers concerning ethical issues in accounting, 2) the researcher sought not to judge rather understand the staff perspectives regarding the role of ethics in the accounting curriculum. Paradigm is concerned with the study of the world from the subjective experience of individuals. In other words, the interpretive paradigm uses individual experiences, perceptions, and opinions to construct and then interpret meaningfully (Thanh \& Thanh, 2015). The interpretive researchers discover reality by analyzing participants' views in the research, their background, and the researcher's background and experiences (Thanh \& Thanh, 2015). Thus, the understanding of the research context is very critical to the interpretation of the data gathered.

The study used a qualitative research design. Qualitative research involves the use of language or words, as well as pictures or observations. Qualitative analysis gives an in-depth view of how and why things have happened. In the study context, this design is suitable as it is an in-depth study of ethical issues in the accounting curriculum involving a few accounting lecturers at UKZN and UNIZULU. The researchers were not interested in a broad perspective, rather a deep understanding of the issues. Qualitative research is gaining importance in the world of research, as it was considered not philosophically congruent to empirical research by the majority of researchers from science. However, qualitative research is now recognized to add a new dimension to empirical research (Gibson et al., 2004).

In terms of research style, the study followed a case study approach and involved a small sample of accounting lecturers from UKZN and UNIZULU. A case study is defined as an in-depth study of a subject or phenomena as well as its related contextual conditions; it can mean single and multiple case studies, can include quantitative evidence, relies on numerous sources of evidence, and benefits from the prior development of theoretical propositions (Yin, 2014; Yazan, 2015). There are various types of case studies in the literature, and they include explanatory case study, multiple or collective, intrinsic case study, and instrument case studies. The explanatory case study focuses on the explanation of the phenomenon being studied. An example would be the airplane accidents of Boeing 737. The exploratory case study explores the phenomenon so that a more intensive task can be done. The multiple or collective case study assimilates information from various sources to formulate a new study case. The study of numerous air crashes of Boeing 737 could be an example of a collective case study. An intrinsic case study is for studying a person or event itself, while an instrumental case study is about the relationship between groups. In brief, a case study can be planned for a single person or group of people, for a specific location or an organization/company, an event itself. The current case study subject is lecturers from the Department of Accounting from two universities-UKZN and UNIZULU. The objective is to understand their reflections concerning the teaching of ethics in the accounting curriculum.

The data generation was done using the structural survey questionnaire (SSQs). SSQ's are a special tool designed to gauge the staff reflections on the inclusion of ethics into the accounting curriculum. The attitudes of lecturers' were measured concerning ethical issues in accounting education with the Likert scale (LS) technique. The Likert scale technique was used to measure the attitudes of respondents concerning a particular issue or statement. The statements were rated in terms of the finalizing responses: strongly agree, agree, neutral, disagree, and strongly disagree. Likert (1932) suggested the Likert scale. A Likert scale is a technique of rating statements, thereby aggregating the sampled population's opinions or perceptions. It is quite commonly used in educational and psychological research. The Likert scale offers a range of answers or agreement or disagreement to a statement. This covers one extreme attitude to another extreme one, such as "extremely likely" to "not at all likely" or "strongly agree" to "strongly disagree." Generally, a five- or seven-point scale can be used. Some researchers have, however, reported higher reliabilities for five-point scales (Jenkins \& Taber, 1977; Lissitz \& Green, 1975; McKelvie, 1978; Remmers \& Ewart, 1941); a five-point scale has been found readily comprehensible to respondents, and it enables them to express their views (Matell \& Jacoby, 1971). The literature also suggests that a five-point scale appears to be less confusing and increases response rate (Babakus \& Mangold, 1992; Devlin et al., 1993). In current practice, most rating scales, including Likert-type scales and other attitude and opinion measures, contain either five or seven response categories (Bearden, Netmeyer, \& Mobley, 1993). The Likert scale is simple and easy to use, which is its strength (Neuman, 2000). Likert scale analysis was supplemented by analysis of open-ended questions, included on the SSQs. Thus, SSQ included two parts - Likert scale and open-ended questions 
Sampling is necessary for a researcher as the cost of surveying the entire population in terms of time, and money may be very high. This is especially true in quantitative method-based research, which employs a generally large sample size. Unlike quantitative research, qualitative research could be based on a small sample size, depending on the study's objective. For example, a case study approach can be made with just one sample. A researcher needs to decide on 1) the sample size, 2) representativeness and parameters of the sample, 3) access to sample, 4) sampling strategy and 5) kind of research-quantitative and qualitative (Cohen et al., 2011, p.143). The correct sample size depends upon the purpose of the study, the nature of the population under scrutiny, the level of accuracy required, the number of variables included in the research, and the type of research methodology (quantitative vs. qualitative) (Cohen et al., 2011, p.144). Generally speaking, for quantitative studies, the sample size should be at least 30 as required for statistical analysis, but this depends upon various factors, as discussed above (for more details, see Cohen et al., 2011). The current study is based on the qualitative method, that too, a case study method. The sample size is not a significant issue. The objective was not to fit a statistical model but rather to understand and learn from the lecturers' reflection concerning the accounting curriculum's teaching of ethics. The case study was based on lecturers' reflections in the Department of Accounting and Auditing at UNIZULU and UKZN.

The purpose here was to make an in-depth understanding of issues as perceived by the lecturers. The sample's representativeness is not a big concern, as one is not dealing with a large number of lecturers in the study design, unlike in a quantitative study. All the lecturers were potentially available and could be contacted by phone or in person or a group with prior arrangement. This was the qualitative research work, non-probability, or purposive sampling suited to be the best (Teddlie \& Yu, 2007). In this case, SSQs were distributed to all lecturers, and more than 80 percent responded. In the FGD, participation was voluntary, and consent was sought before proceeding with the discussion. This provided the researcher with an opportunity to make an in-depth inquiry.

\section{Trustworthiness}

There exists an essential difference between qualitative and quantitative research. In qualitative research, trustworthiness issues are more important than validity and reliability (Lincoln \& Guba, 1985). The qualitative and quantitative analyses should be seen as complementing each other, rather than as incompatible (Malterud, 2001). This is because qualitative researchers do not use instruments that can measure validity and reliability in quantitative research; hence, qualitative researchers use the concept of trustworthiness. The study's trustworthiness or rigour refers to the extent one has confidence in data, interpretation, and methods used to ensure the quality of the research (Polit \& Beck, 2014).

Trustworthiness is defined as the ability to use credibility, transferability, confirmability, and dependability to make the studies reliable (Lincoln \& Guba, 1985). All these parameters address the question of trustworthiness well enough. Trustworthiness is broken down into various factors: 1) credibility, 2) transferability, 3) dependability, and 4) credibility. According to Lincoln and Guba (1985, p. 290), the fundamental question addressed by the notion of trustworthiness is simple: "How can an inquirer persuade his or her audiences that the research findings of an inquiry are worth paying attention to?"

The study's credibility or confidence in the study is credibility (Polit \& Beck, 2014). This concept is equivalent to internal validity in quantitative research. Credibility thus depends on the richness of the researcher's information gathered and analytical abilities (Patton, 1990). Credibility can be enhanced by triangulation; triangulation in methods, data, multiple analysis, and themes (Patton, 1990). Credibility is ensured in the study by providing that the data measures what it was supposed to measure. Credibility provides confidence or belief in the trustworthiness of data through a) persistent observation, b) prolonged engagement, c) referential adequacy, d) peer debriefing, and e) member checks, depending upon the context. In the process of data collection, all these procedures were observed. For example, all discussions were voluntary and were recorded, written, and verified by the researcher.

Transferability is equivalent to external validity in quantitative research. It means the ability to generalize findings across different settings. Although generalizability is a preferred objective of any research, all research is not generalizable, particularly qualitative research. The existence of local conditions makes it difficult to generalize (Lincoln \& Guba, 1985:124). One should note that qualitative researchers discuss and focus on the informants' information and their story, without saying that this is everyone's story (Connelly, 2016).

Kirk and Miller (1986, pp. 41-42) identify three types of reliability referred to in the conventional research, which relate to 1) the degree to which a measurement, given repeatedly, remains the same; 2 ) the stability of a measurement over time, and 3) the similarity of measurements within a given period. They note, "issues of reliability have received little attention" from qualitative researchers, who have instead focused on achieving greater validity in their work (p. 42). Although they give several examples of how reliability might be viewed in a qualitative framework, Lincoln and 
Guba (1985) sum up the essence of these examples in the following statement: "Since there can be no validity without reliability (and thus no credibility without dependability), a demonstration of the former is sufficient to establish the latter" (p. 316). Nevertheless, Lincoln and Guba (1985, p. 317) propose one measure that might enhance the dependability of qualitative research. That is the use of an "inquiry audit", in which reviewers examine both the process and the product of the research for consistency. In brief, dependability is the extent to which other researchers could repeat the study, and the findings would be consistent. This means all information for the research report is available to readers for replication of the work. In the context of the study, dependability is achieved by matching empirical results with literature review relating to the staff's reflection on ethical issues in the accounting curriculum. The researchers also played the role of inquiry audit so that the dependability of research was ensured. This was done through the consultation process.

Confirmability is the degree of neutrality in research findings. In other words, findings should be based on participants' responses and not on any personal interpretations of the researcher. The researcher should stay neutral and report results as such. Researchers should, therefore, remain non-judgmental and should not skew the interpretation of findings. This can be done through a transparent confirmability audit. By providing an audit trail of raw data, analysis notes, process notes, personal notes, etc. (Lincoln \& Guba, 1985, pp. 319-321). In the study's context, this was achieved by the questions being framed in such a manner that they were not be led into a particular way of answering the questions.

\section{Ethical Issues}

The following steps were taken to ensure that ethical issues were adequately addressed: 1) the researcher sought permission by writing to the Registrar or Dean of UKZN or UNIZULU, requesting the lecturers' participation in the focus group interviews and structured survey questionnaires and focus group discussions, 2) the researcher also applied to get ethical clearance form from UKZN and UNIZULU, 3) an informed consent form signed by the participants was also adhered to, and 4) the researcher ensured that no harm was done to the participants and that information gotten from them were kept confidential. The no harm clause was ensured through the voluntary participation of respondents, and respondents were given the freedom to withdraw at any time they wished. Ethical issues mainly consisted of four components: informed consent, anonymity, sources of tension, and confidentiality. A brief explanation of these factors is described below.

Informed consent includes four elements: competence, voluntarism, full information, and comprehension (Cohen et al., 2011, p. 78). Competence refers to mature and responsible participants, assuming that they would make correct decisions when given relevant information. Voluntarism implies the freedom to participate or not. Full information refers to the fact that complete information about the study and how it would be used is explained to the participants. Comprehension implies that participants understand the research project and rules (Cohen et al., 2011, p. 78). Informed consent of participants in the research ensures ethicality. This ensures participants' freedom of rights and self-determination (Cohen et al., 2011, p. 77). The participants were given the freedom to refuse to participate or withdraw in between from the research process. Informed consent was assured while collecting data from staff and students, and individual responses were kept confidential.

In summary, informed consent is regarded as the process of getting permission to conduct the study. The respondents were assured of complete voluntary participation at all costs. Their identities and names were hidden, and they could use pseudonyms to protect their identities. They were also allowed to withdraw at any stage during the study.

Privacy or confidentiality of participants is a requirement for conducting ethical research (Lincoln, 1990). The anonymity of participants is generally used to protect them (Oliver, 2010). On the part of the researcher, it is imperative to maintain the information provider's confidentiality as much as possible. The researcher may not publicly decline who the participants are - the research adhered to good research principles as laid out in the University's ethical clearance guide. There are two main principles that the research followed: 1) anonymity and 2) confidentiality. Anonymity is of utmost importance in the study. The respondent's names were kept anonymous, and they were provided with pseudonyms to protect their identity. Similarly, confidentiality is of utmost importance as it adds value to the study.

In terms of confidentiality, the researcher has signed a confidentiality agreement with the University Ethical Research Committee. This agreement says all the results will be kept confidential by the university. The results will not be disclosed to outsiders.

The study is uniquely South African and localized in the context and focuses on the undergraduate accounting programme at the two universities - UKZN and UNIZULU - only. 


\section{Results and Discussions}

As discussed above, two universities were included-UKZN and UNIZULU. It is important to note that ethics is taught as per the recommendation of the SAICA core syllabus at all South African universities (SAICA, 2018). This is part of the competency framework, which is designed to produce competent Chartered Accountants (CA(SA)); the competency framework relates to the competencies of CA at the entry point of the profession (SAICA, 2018). Before 2010, SAICA emphasized a knowledge-based syllabus for CAs; the training programme was also designed to identify outcomes in the form of core experience requirements (SAICA, 2018, p. 5). These approaches were later found inconsistent as academic and training programmes were not fully complementing each other (SAICA, 2018, p. 5). The competency programme was then developed/modified to re-orient the CA profession and improve professional practice (SAICA, 2018). The teaching of ethics hence became an important part of both academic and training programmes. Ethics is now fully integrated into SAICA's competency framework, as discussed in Chapter 2 (See Figure 1). Ethics covers roughly 5-10 percent of total marks in the Initial Test of Competency (ITC)(20-40 marks out of 400 marks), and ethics (specifically the identification and response to ethical dilemmas) is now assessed in the second Assessment of Professional Competencies (APC) examination (Based on email communication from Mandi Olivier, 13 September 2018). SAICA has now recommended a full course of 12 weeks or a semester-long course on business and professional ethics for the B.Com accounting programme. The delivery, however, is flexible and can be decided by the universities. The material can be delivered as a single semester course, as two-half semester courses, or a series of sections integrated into existing courses (SAICA, 2018, Appendix 2-Guidance on the Teaching of Ethics).

At UKZN, an ethics module is taught to B.Com accounting students in the second year. This is a 12 weeks course consisting of four lectures per week of 45 minutes each. The course's name is Ethics, Business and Accounting; the suggested assessment includes a coursework assignment (40\%) plus a three-hour final examination (60\%). The assignment can be in the form of class-tests, a mini assignment about ethics in accounting. Students are asked to maintain a learning journal and record their learning experiences concerning ethics, linking the course content with ethically relevant events and issues encountered globally, including news media, personal experiences, etc. The course content follows the SAICA's (2018) guidelines on ethics teaching (see Appendix 2 of SAICA, 2018). It has three sections. Section one covers an introduction to applied ethics in four weeks, covering a sound introductory understanding of individuals and society's ethical dimension and selected ethical theories; this allows students to link case material with ethical knowledge and theory and develop the ability to make an ethical decision concerning the case study. Section two covers business ethics in four weeks. The material covered includes an introductory understanding of socio-economic, ethical issues related to business and professional practice, an introductory understanding of the associated problems and approaches to business ethics in South Africa and the world, and management skills concerning ethics. The third section of four weeks covers knowledge of professionalism and its ethical aspects, understanding of professional codes, knowledge of main ethical issues in accounting profession, etc. The SAICA Code of Professional Conduct is also discussed here. A sample of the SAICA Code is shown in Table 5.1. The course's primary objective is to develop the ability to handle ethical issues in the business and profession. Interestingly enough, part of this course is the reflective learning component whereby students must maintain a learning journal to record, comment, evaluate, and interpret their learning experiences. The word count for this journal is 3000 words.

The book Ethics for Accountants and Auditors (Kretzschmar et al., 2019) is used as a textbook. Other recommended readings include Roussouw and Vuuren (2017) and Brookes and Dunn (2017). In short, the course at UKZN is very extensive and comprehensive. This reflexive learning allows students to concisely look at and think about their experiences and responses and then interpret them to learn from them. Students asked themselves what they did, how they did, and what they learned from it. The learning reflection reports are submitted every month to the lecturer to evaluate the learning progression. Reflection promotes critical thinking and higher-order thinking skills. Each section of the course aims to develop students' abilities to link theoretical knowledge to a case study and learn to make ethical decisions. Thus new Bloom's taxonomy is fully employed; students are asked to create the knowledge and apply it in real-life situations given their constraints. 
Table 1. A sample of the ethics syllabus as suggested by SAICA

\begin{tabular}{ll}
\hline IA: & Ethical behaviour and Professionalism \\
\hline IA-1 & Uses and ethical reasoning process \\
\hline IA-2 & Protects the public interest \\
\hline IA-3 & Act competently with honesty and integrity \\
\hline IA-4 & Perform work competently and with due care \\
\hline IA-5 & Maintain objectivity and independence \\
\hline IA-6 & Avoids conflicts of interest \\
\hline IA-7 & Protects the confidentiality of information \\
\hline IA-8 & Maintains and enhances the profession's reputation \\
\hline IA-9 & $\begin{array}{l}\text { Adheres to laws, professional standards and policies and the rules of professional conduct when } \\
\text { exercising professional judgement. }\end{array}$ \\
\hline
\end{tabular}

Ethical behaviour and professionalism is the first of three categories of the "Pervasive qualities and skills" that is, those qualities that a CA brings to any task.

Whether recently qualifues or highly experienced, all CAs are required to uphold ethical principles and conduct themselves professionally. Acting with integrity, through adherence to these values, is fundamental to the professions's commitment to excellence and the public interest.

Source: SAICA (2018, p., 31).

At UNIZULU, the ethics module (Business Ethics) is taught in the second year for 12 weeks. It follows the SAICA outline for the ethics course. It follows almost the same outline as done by UKZN, and hence discussion is not repeated here. The book, Ethics for Accountants and Auditors by Kretzschman et al. (2012), was used as the prescribed textbook; the new edition is now being required for the coming year. The course's major purpose is to sensitize students to ethical issues, themes and enable them to make decisions ethically following the principles of ethics and the SAICA professional code. The course uses the professional code as compulsory reading. The course also uses reflective reports as part of self-assessment activities. This gives them the chance to learn what they did wrong and right and how it can be improved. Students are given group assignments as part of experimental learning; this promotes sharing knowledge and becoming co-creators in the knowledge building process.

An analysis of modules on ethics at UKZN and UNIZULU revealed that they were almost the same and aligned with SAICA's guidelines. Bloom's taxonomy module is followed as per SAICA guidance. An ability to analyse and decide with the help of ethical theories and principles is developed in the students. Ethics teaching has taken hold in accounting programmes in both universities.

\section{Reflections of Academics}

At the outset, a brief discussion on sample characteristics is essential. The Department of Accounting and Auditing at UNIZULU had some 16 lecturers, and 12 of them filled out the SSQs, the response rate being about 75 percent. In contrast, the Department of Accounting and Auditing in UKZN had some 24 lecturers, but only seven lecturers agreed to fill out the SSQs - the response rate being 33 percent.

The results from the Likert scale analysis are discussed below. The Likert scale was used to describe and analyse lecturers' reflections on ethics in the accounting curriculum. Some 19 lecturers were selected and asked to reflect on the issues of ethics in the accounting curriculum. There were six questions asked to lecturers, which had to be rated on a five-point rating scale where 1 stands for strongly disagree and 5 stands for strongly agree (1-strongly disagree, 2-Disagree, 3-Neutral, 4-Agree, 5-Strongly agree). Each statement's aggregate score from number 1 to 6 for UKZN and UNIZULU and overall aggregate score over both institutions are given in Table 2.

Statement number 1: As a lecturer, I have made changes in the accounting curriculum after 1994 to represent South African society.

Statement 1 has an overall aggregate score of 3.54 (3.57 for UKZN and 3.50 for UNIZULU). Several 3.54 represents an agreement with the statement. This means that lecturers concur that there have been changes in the accounting 
curriculum after 1994. The open-ended questionnaire does answer or explain this well. For example, the following statements by lecturers confirm and support the Likert score showing agreement to the statement:

Lecturer A (UKZN): The focus is on being a business leader and less technical in the disciplines. This is because the volume has increased tremendously.

Lecturer B (UNIZULU): There has been a much-increased emphasis on the International Accounting and Auditing Standards (IFRSS and ISA'S).

Lecturer C (UKZN): There is more inclusiveness with a tremendous technical increase (move legislation). It is more focused on bridging the gap between theoretical knowledge and what happens in practice.

Table 2. Aggregate responses of lecturers towards reflection on ethics in accounting curriculum at UKZN

\begin{tabular}{|c|c|c|c|c|}
\hline Statement & $\begin{array}{l}\text { Average } \\
\text { Likert scale } \\
\text { score UKZN }\end{array}$ & $\begin{array}{lr}\text { Average } & \text { Likert } \\
\text { scale } & \text { score } \\
\text { UNIZULU }\end{array}$ & $\begin{array}{l}\text { Overall } \\
\text { average } \\
\text { Likert score }\end{array}$ & $\begin{array}{l}\text { Overall } \\
\text { modal } \\
\text { Likert score }\end{array}$ \\
\hline $\begin{array}{l}\text { 1. As a lecturer, I have made changes in } \\
\text { the accounting curriculum after } 1994 \text { to } \\
\text { represent South African society. }\end{array}$ & 3.57 & 3.50 & 3.54 & 4 \\
\hline $\begin{array}{l}\text { 2. Ethical issues and obligations of CAs } \\
\text { are well covered in the curriculum. }\end{array}$ & 4.14 & 3.75 & 3.95 & 5 \\
\hline $\begin{array}{l}\text { 3. An understanding of ethical issues } \\
\text { and ethical behaviour should be part of the } \\
\text { accounting curriculum to produce CAs. }\end{array}$ & 4.00 & 4.41 & 4.21 & 5 \\
\hline $\begin{array}{l}\text { 4. The accounting profession } \\
\text { must } \\
\text { impose a strict ethical code for CAs }\end{array}$ & 4.14 & 4.41 & 4.28 & 4.5 \\
\hline $\begin{array}{l}\text { 5. Ethics should be made an integral part } \\
\text { of the entire accounting curriculum and } \\
\text { must be discussed and addressed at all } \\
\text { training levels. }\end{array}$ & 4.28 & 4.33 & 4.31 & 5 \\
\hline $\begin{array}{l}\text { 6. The demographic change after } 1994 \\
\text { in student population at the university has } \\
\text { caused a drop in academic standards }\end{array}$ & 3.71 & 2.33 & 3.02 & 3 \\
\hline
\end{tabular}

Source: Compiled from survey data.

Three types of changes in the curriculum are mentioned. Firstly, the curriculum is now more business-oriented and emphasizes technicality as it was before. Secondly, it confirms that new increased emphasis is being given on international accounting and auditing standards. Thirdly, the curriculum is now more focused on theoretical knowledge's practical application, and the gap between practical and theory is being bridged. Fourth, it confirms that the curriculum is now more inclusive or covers indigenous cultural aspects and less Euro-centric.

Statement number 2: Ethical issues and obligations of CAs are well covered in the curriculum.

Statement number 2 comes with an overall aggregate score of 3.95 - indicating an agreement with the statement. However, modal (maximum frequent score) is 5 - further confirming that SAICA has incorporated ethical issues very well into the curriculum. Some of the quotes from the open-ended section back the above assertion:

Lecturer A (UKZN): More diversity, more excellent representation of South Africa.

Lecturer B (UNIZULU): More emphasis on ethics, Black clients require more bookkeeping resources and explanations.

Lecturer C (UNIZULU): There is an increased emphasis on ethics, and people are more involved in ethics.

Two significant changes are observed: one, greater diversity in the discipline and servicing the black community. Two, ethics is being given more emphasis, unlike in the past, in South Africa. 
Statement number 3: An understanding of ethical issues and ethical behavior should be part of the accounting curriculum to produce CAs who can uphold the profession's integrity.

Statement number 3 fetches an overall mean score of 4.21 and a modal score of 5 . Lecturers strongly agree with the statement. Lecturers do believe that more emphasis on ethics in the curriculum and business is needed. Some of the quotes from the open-ended questions back this assertion:

Lecturer A (UKZN): Many ethical issues surround us in our lives. It is essential to believe that ethics plays a critical role in the business world.

Lecturer B (UKZN): Ethical issues abound in the (UKZN) accounting curriculum. Corporate governance is becoming important now.

Lecturer C (UNIZULU): Ethics is now governed by the King Code and SAICA code of professional conduct.

Two important perceptions are that ethics has become more critical in the business world, and ethical issues are being covered in the curriculum. For example, at UKZN, more emphasis is on corporate governance and ethical issues. At the same time, at UNIZULU, it is the same but expressed differently, i.e., King Code and SAICA's professional code of conduct are referred to as the key document for corporate and professional ethical governance.

Statement number 4: The accounting profession must impose a strict ethical code for CAs.

Statement number 4 has an overall aggregate mean score of 4.28 , and modal scores are 4 and 5, i.e., an equal number of lecturers chose the responses 4 and 5. Lecturers, in general, strongly agree with the imposition of a strict code of ethics for CAs. A high modal score of 4 and 5 confirm it strongly. Some quotes from the open-ended questions support this claim:

Lecturer A (UKZN): A strict ethical code for CAs, must be imposed in the profession.

Lecturer B (UKZN): The code must reflect the economic needs of the South African Society.

Lecturer C (UNIZULU): The code must be ratified by law, and whistleblowing should be encouraged.

A strict code and its implementation are warranted, and whistleblowing is an important activity to keep business ethical.

Statement number 5: Ethics should be made an integral part of the entire accounting curriculum and must be discussed and addressed at all training levels.

Statement number 5 has an overall mean score of 4.31 and a modal score of 5, suggesting a very high agreement with the statement. Some quotes from the open-ended question provide high agreement with the statement.

Lecturer A (UKZN): Ethics is an integral part of the accounting curriculum, and I love it.

Lecturer B (UKZN): Ethics must be incorporated into the accounting curriculum and beneficial to students.

Lecturer C (UNIZULU): Ethics is an essential part of the curriculum and must be adhered to by all.

Statement number 6: The demographic change after 1994 in the university student population has caused a drop in academic standards.

Statement number 6 has an overall aggregate score of 3 and a modal score of 3 as well. This shows overall neutrality or a level of disregard for the statement. However, at the same time, they have not taken a position that the statement is altogether not correct. Overall, lecturers, in general, do not agree that academic standard has lowered after 1994; but open-ended question bring it out as below:

Lecturer A (UNIZULU): The demographic change has dropped the university standards.

Lecturer B (UNIZULU): It is essential to see that the Africanisation of Universities has caused a tremendous drop in academic standards.

Lecturer C (UNIZULU): A drop in academic standards is inherited in the curriculum after 1994. This is because Africans are entering the institution.

From the above statement, it is clear that it is a mixed response to the statement. Some believe that academic standards have come down, while some disagree with it.

An overall summary from the above analysis has emerged (See Table 5.2). Firstly, all the mean scores for UNIZULU and UKZN are very similar, and the distance between the two is marginal, except for statement number 6 (See Table 5.2). For the first five statements, the overall mean score is hovering around 4, suggesting both UNIZULU and 
UKZN lecturers concur in their perception of these statements. However, the last statement, number 6 , fetches a mean score of 2.33 for UNIZULU and 3.71 for UKZN. UNIZULU lecturers thus perceive that academic standards have not gone down, while in contrast, UKZN lecturers tend to agree with the statement (mean score of 3.71). However, the overall score of 3.02 thus brings it to the neutrality position.

Secondly, lecturers at both UKZN and UNIZULU opined that ethical issues and the objectives of CA are well-covered in the curriculum, and they opined for a much stricter code for CAs. Previous studies have also confirmed that the study of ethics education positively impacts accounting students' ethical judgment and ethical reasoning level (Welton \& Guffey, 2009; Gau, 2010; Martinov-Bennie \& Mladenovic, 2015). The overall opinion of lecturers thus further supports the wisdom from the review of the literature.

Thirdly, as part of the accounting curriculum, ethics is being given utmost importance by the lecturers. Integration of ethics into the accounting curriculum is the desired result and recommended by experts (Martinov-Benonie \& Mladonovic, 2015; Cooper et al., 2008). Table 3 provides the most frequent response of lectures at UNIZULU and UKZN (modal response). This confirms that most lecturers assigned either 4 or 5 in most statements and agree with the statement.

Table 3. Most frequent response of lectures at UNIZULU and UKZN

\begin{tabular}{lll}
\hline Statement & Mode of UKZN & Mode of UNIZULU \\
\hline 1 & 5 & 4 \\
\hline 2 & 5 & 4 \\
\hline 3 & 4 & 5 \\
\hline 4 & 4 & 5 \\
\hline 5 & 4 & 5 \\
\hline 6 & 4 & 3
\end{tabular}

Source: Based on Table 2.

\section{Conclusions}

The study was based on lecturers' reflections towards ethics in the accounting curriculum, based on the case study of UKZN and UNIZULU. Ethics is hence seen as an important part of the curriculum of accounting science. Studies have confirmed that accounting graduates' ethical training improves their ethical sensitivity and produces better ethical sensitive graduates. Currently, 12 weeks course of ethics is included to cover ethical issues in both universities-UKZN and UNIZULU. Many studies in the literature suggest that ethics should be integrated into each course, and it has a long time influence on graduates in this manner. It is recommended that a mid-way approach should be popularized. That is, ethical content coverage in the accounting curriculum should go beyond a single course. A single course is good and provided a good grounding in ethical knowledge, theories, and application. However, the impacts are not long-lasting. The study suggests that special topical issues on ethics should be examined again in each course. For example, in the auditing course, ethical procedures should be touched upon, and students should be sensitized about accountants' ethical behaviour. This is in line with SAICA's guideline, which defines that ethics or ethical behaviour affects all process of CA(SA): business acumen, digital acumen, relational acumen, decision-making acumen The other recommendation that comes is that ethical teaching should be conducted with more practical situations in the analysis of ethical dilemma. This would sensitize students in the prequalification stage of CA.

The other important recommendation that emanates is about the teaching of ethics should be linked to a reality check. Based on lecturers' reflections, it was revealed that teaching ethics should involve the practical professionals in the classroom to assure students that this does happen and ethics is an important issue for the professionals. According to Kretzschmar and Bentley (2013), stakeholders such as professional institutions and higher education institutions also improve the confidence of lecturers and students in teaching and learning ethics in the accounting curriculum. This leads to a belief among students that ethics matters in the business world, and it is just not limited to passing a course on ethics. 


\section{References}

Adler, P. S. (2002). Corporate scandals: It's time for reflection in business schools. Academy of Management Perspectives, 16(3), 148-149. https://doi.org/10.5465/ame.2002.8540425

Ahmad, K. (2007). Interviewing accounting students in ethics in the curriculum. Journal of Business Ethics, 3(2), 87-95.

Babakus, E., \& Mangold, W. (1992). Patient adapting to the servqual scale to hospital services: An empirical investigation. Health Services Research, 26(6), 767-86.

Bayou, M. E., Reinstein, A., \& Williams, P. F. (2011). To tell the truth: A discussion of issues concerning truth and ethics in accounting. Accounting, Organizations and Society, 36(2), 109-124. https://doi.org/10.1016/j.aos.2011.02.001

Bearden, W. O., Netmeyer, P. G., \& Mobley, M. F. (1993). Handbook of marketing scales: Multi-item measures for marketing and consumer behavior research. Newbury Park, CA: Sage.

Brookes, L. J., \& Dunn, P. (2017). Business and professional ethics for directors, executives and accountants (6th ed.). Mason, Ohio: South Western Cengage Learning.

Cavanaugh, S. H. (1993). Connecting education and practice. In L. Curry, \& J. F. Wergin (Eds.), Educating professionals: Responding to new expectations for competence and accountability (pp. 107-125). San Francisco: Jossey Bass Publishers.

Chan, S. Y. S., \& Leung, P. (2006). The effects of accounting students' ethical reasoning and personal factors on their ethical sensitivity. Managerial Auditing Journal, 21(4), 436-457. https://doi.org/10.1108/02686900610661432

Chawla, G., \& Nanhas, P. S. (2015). Sustainability in higher education: An exploratory investigation of hospitality management courses. Journal of Innovation in Hospitality and Tourism, 4(1), 19-42. https://doi.org/10.7603/s40930-015-0002-x

Chawla, S. K., Khan, Z. U., Jackson, R. E., \& Gray III, A. W. (2015). Evaluating ethics education for accounting students. Management Accounting Quarterly, 16(2), 16-25.

Chen, C., Gotti, G., Kang, T., \& Wolfe, M. C. (2018). Corporate codes of ethics, national culture, and earnings discretion: International evidence. Journal of Business Ethics, 151(1), 141-163. https://doi.org/10.1007/s10551-016-3210-y

Cheng, K. W. (2007). The curriculum design in universities from the perspectives of providers in accounting education. Education, 127(4), 581-590.

Cohen, C., \& Pant, A. (1991). Can ethics be taught in accounting?. Journal of Accounting Education, 11(2), 185-209. https://doi.org/10.1016/0748-5751(93)90002-Z

Cohen, L., Marion, L., \& Morrsion, K. (2011). Research methods in education. London: Routledge.

Connelly, L. M. (2016). Trustworthiness in qualitative research. Medsurg Nursing, 25(6), 435-436.

Cooper, B. J., Leung, P., Dellaportas, S., Jackling, B., \& Wong, G. (2008). Ethics education for accounting students: A toolkit approach. Accounting Education: An International Journal, 17(4), 405-430. https://doi.org/10.1080/09639280802436681

Cowton, C. J., \& Cummins, J. (2003). Teaching business ethics in UK higher education: progress and prospects. Teaching Business Ethics, 7(1), 37-54. https://doi.org/10.1023/A:1022665221990

Dellaportas, S., Gibson, K., Alagiah, R., Hutchinson, M., Leuney, P., \& Van Homrigh, D. (2005). Ethics, governance and accountability: A professional perspective. Milton, Queensland: John Wiley.

Devlin, S. J., Dong, H. K., \& Brown, M. (1993). Selecting a scale for measuring quality. Marketing Research: A Magazine of Management and Applications, 5(3), 12-17.

Gibson, A., Timlin, A., Curran, S., \& Wattis, J. (2004). The scope for qualitative methods in research and clinical trials in dementia. Age Ageing, 33, 422-426. https://doi.org/10.1093/ageing/afh136

Johnson, R. B., \& Christensen, L. (2014). Educational research: Quanitative, qualitative and mixed approaches (5th ed.). Los Angeles: Sage. 
Kelly, P. (2017). Developing ethical leaders for the accounting profession: finding inspiration from Coast Guard Academy. CPA Journal. $\quad$ Retrieved from https://www.cpajournal.com/2017/03/20/developing-ethical-leaders-accounting-profession/

Kirk, J., \& Miller, M. L. (1986). Reliability and validity in qualitative research. Qualitative Research Methods Series, London: Sage. https://doi.org/10.4135/9781412985659

Kretzschmar, L., \& Bentley, W. (2013). Applied ethics and tertiary education in South Africa: Teaching business ethics at the University of South Africa. Verbum et Ecclesia, 34(1), 1-7. https://doi.org/10.4102/ve.v34i1.804

Kretzschmar, L., Prinsloo, F., Prozesky, M., Rossouw, D., Sander, K., Siebrits, J., ... Woermann, M. (2012). Ethics for accountants and auditors (3rd ed.). Cape Town: Oxford University Press.

Kretzschmar, L., Prinsloo, F., Sander, K., Siebrits, J., Vuuren, L., \& Vorster, P. (2019). Ethics for accountants and auditors (4th ed.). Cape Town: Oxford University Press.

Likert, R. (1932). A technique for the measurements of attitudes. Archives of Psychology, 140(22), 5-55.

Lincoln, Y. S., \& Guba, E. G. (1985). Naturalistic inquiry. Beverly Hills, CA: Sage. https://doi.org/10.1016/0147-1767(85)90062-8

Lissitz, R. W., \& Green, S. B. (1975). Effect of the number of scale points on reliability: A Monte-Carlo approach. Journal of Applied Psychology, 60(1), 10-13. https://doi.org/10.1037/h0076268

Loeb, S. E. (1988). Teaching students accounting ethics: some crucial issues. Issues in Accounting Education, 3, 316-329.

Malterud, K. (2001). Qualitative research: Standards, challenges and guidelines. The Lancet, 358(9280), 483-488. https://doi.org/10.1016/S0140-6736(01)05627-6

Martinov-Bennie, N., \& Mladenovic, R. (2015). Investigation of the impact of an ethical framework and an integrated ethics education on accounting students' ethical sensitivity and judgment. Journal of Business Ethics, 127(1), 189-203. https://doi.org/10.1007/s10551-013-2007-5

Massey, D. W., \& Van Hise, J. (2009). Walking the walk: Integrating lessons of an accounting ethics course. Issues in Accounting Education, 24(4), 481-510. https://doi.org/10.2308/iace.2009.24.4.481

Matell, M., \& Jacoby, J. (1971). Is there an optimal number of alternatives for Likert scale items? Study 1: Reliability and Validity. Educational and Psychological Measurement, 31, 657-674. https://doi.org/10.1177/001316447103100307

McKelvie, S. J. (1978). Graphic rating scales: How many categories?. British Journal of Psychology, 69(2), 185-202. https://doi.org/10.1111/j.2044-8295.1978.tb01647.x

McPhail, K. (2001). The other objective of ethical education: Re-humanising the accounting profession - a study of ethics education in law, engineering, medicine and accounting. Journal of Business Ethics, 34(3-4), 279-298. https://doi.org/10.1023/A:1012576631990

Mujtaba, B. (2005). Understanding ethics and morality in business. Retrieved from http://www.sbnonline.com/2005/04/understanding-ethics-and-morality-in-business-there-are-distinctdifferences -between-ethics-and-morality/

Neuman, W. (2000). Social research methods: qualitative and quantitative approaches (4th ed.). Needham Heights: Allyn \& Bacon.

Oxford English Dictionary (3rd ed.). (2000). Oxford University Press.

Patton, M. Q. (1990). Qualitative evaluation and research methods (2nd ed.). London: Sage.

Pollit, D. F., \& Beck, C. T. (2014). Essentials of nursing research: Appraising evidence for nursing Practice (8th ed.). Philadelphia, PA: Wolters.

Prozesky, M. (2001). Ethics in the education of South African Chartered Accountants. Report prepared for the South African Institute of Chartered Accountants. Pietermaritzburg: Unilever Ethics Centre, University of Natal.

Remmers, H. H., \& Ewart, E. (1941). Reliability of multiple-choice measuring instruments as a function of the Spearman-Brown prophecy formula, III. Journal of Educational Psychology, 32(1), 61-66. https://doi.org/10.1037/h0061781

Riley, G. (2012). What is right or wrong?. Journal of Accounting Business Ethics, 4(3), 100-125. 
Rossouw, D., \& Van, V. (2017). Business ethics (6th ed.). Cape Town: Oxford University Press.

Russel, K. A., \& Smith, C. S. (2003). Accounting education's role in corporate malfeasance: It's time for new curriculum. Journal of Business Ethics, 3(4), 87-90.

SAICA. (2018). Competency framework detailed guidance for the academic programme: competencies of a CA (SA) at the point of the Initial Test of Competence (ITC) (Assessment at Core Technical Knowledge).

SAICA. (n.d.) Thought leadership initiative: CA2025. Retrieved from www.saica.co.za/thoughtleadershipinitiatives/CA2025/tabid/4097/language/en-ZA

SAICA. (n.d.). The South African institute of chartered accountants. Retrieved from https://www.saica.co.za/trainees/becomingaCA/tabid/157/language/en-za/Default.aspx

Schwartz, M. S. (2001). A code of ethics for corporate code of ethics. Journal of Business Ethics, 4(2), 27-43.

Schwartz, M. S. (2005). Universal moral values for corporate codes of ethics. Journal of Business Ethics, 59(1-2), 27-44. https://doi.org/10.1007/s10551-005-3403-2

Smith, C. M. (2003). Learning and unlearning: the education of teacher educators. Teaching and Teacher Education, 19(1), 5-28. https://doi.org/10.1016/S0742-051X(02)00091-4

Teddlie, C., \& Yu, F. (2007). Mixed methods sampling: a typology with examples. Journal of Mixed Methods Research, 1(1), 77-100. https://doi.org/10.1177/1558689806292430

Thanh, N. C., \& Thanh, T. T. L. (2015). The interconnection between interpretevist paradigm and qualitative methods in education. American Journal of Education Sciences, 1(2), 24-77.

Titard, P. L., Braun, R. L., \& Meyer, M. J. (2004). Accounting education: Response to corporate scandals. Journal of Accountancy, 198(5), 59-65.

Williams, J., \& Elson, R. J. (2010). The challenges and opportunities of incorporating accounting ethics into the accounting curriculum. Journal of Legal Ethical and Regulatory Issues, 13(1), 105-116.

Wright, L., \& Bline, J. (1998). Are accountants ethical?. Journal of South African Business Ethics, 6(3), 100-119.

Wyatt, A. R., \& Gaa, J. C. (2004). Accounting professionalism: A fundamental problem and the quest for fundamental solutions. The CPA Journal, 1(1), 6-20.

Yazan, B. (2015). Three approaches to case study methods in education: Yin, Merriam and Stake. The Qualitative Report, 20(2), 134-152.

Yin, R. K. (2014). Case study research design and methods (5th ed.). Thousand Oaks, CA: Sage.

\section{Copyrights}

Copyright for this article is retained by the author(s), with first publication rights granted to the journal.

This is an open-access article distributed under the terms and conditions of the Creative Commons Attribution license (http://creativecommons.org/licenses/by/4.0/). 